\title{
A Way to Decrease the Negative Impact of Aquaculture on other Marine Inhabitants
}

\author{
Delik Dokkovich Gabaev \\ National Scientific Center of Marine Biology, Russian Academy of Science, Vladivostok 690041, Russia
}

\begin{abstract}
Spat collectors deployed at sea, in addition to the target species, attract also many larvae of accompanying species, which die after transplanting the cultivated one into cages. However, these juveniles often have a higher value than the cultivated species, and their mortality is caused by smaller sizes. These are: red king crab, Japanese sea cucumber, sea urchins, Japanese cucumaria and several species of ascidians and sponges. However, the use of a realized niche, rather than a fundamental one, in selecting the area and depth to install collectors, and also improvement of their design, make it possible to cultivate a target species without reseeding to other constructions. This not only facilitates the cultivation process, but also increases the survival rate of the cultivated and accompanying species, since at the bottom, they reach either marketable or viable size in comfortable conditions.
\end{abstract}

Keywords: Collector-cage, Patinopecten (Mizuhopecten) yessoensis, Apostichopus japonicus, Paralithodes camtschaticus, Scapharca broughtoni.

\section{Introduction}

The technology for cultivation of the scallop Patinopecten yessoensis, originally borrowed in Japan, has a labor-intensive operation: transplantation of the young from collectors to cages in autumn [1]. Depending on productivity of the year, $30 \%$ to $50 \%$ of young scallops are lost during this above-water operation [2], and the survived individuals experience stress that results in a slowdown of their growth and causes a "ring of interference" to form on their shell. The species accompanying the scallop, even when they get onto the bottom, almost all die due to their small size. This phenomenon was long given the term "ecological trap" [3]. The labor intensiveness of this technology makes it unprofitable both in Russia [4] and in Europe [5]. The studies aimed at optimizing the cultivation process [6-13] and reducing the number of scallop reseeding operations [14] have been conducted for a long time.

$P$. yessoensis that have reached one year of age in collectors or cages are often reseeded onto the bottom,

Corresponding autor: Delik Dokkovich Gabaev, Ph.D., hydrobiologist, research field: mariculture. where they become exposed to many negative factors contributing to their low survival. The experiments for the study of realized niche in scallop and the tests of the new design of the collectors set on the bottom allow us to improve the borrowed technologies and avoid above-water operations with bivalves. The goal of this work is to find the opportunities of growing some commercial bivalves to a marketable size without transplantation.

\section{Materials and Methods}

To achieve this goal, the optimum time for immersing the collectors in order to create the optimum number of young scallops in them was determined first. The determination began with the study of dynamics of the gonadal index in spawners. Every ten days, starting from the mid-May to late-June, 1977-1990, a total of 25-30 scallops were collected by divers in Minonosok Cove of Possyet Bay (42³6’ N, 130 ${ }^{\circ} 51^{\prime}$ 'E ) (Fig. 1), and their total weight, weight of soft tissues, muscle and gonads of the scallops were measured with an accuracy of $\pm 0.02 \mathrm{~g}$. A similar work was carried out

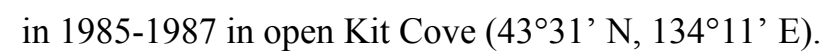
The gonadal index of scallops was estimated by the 


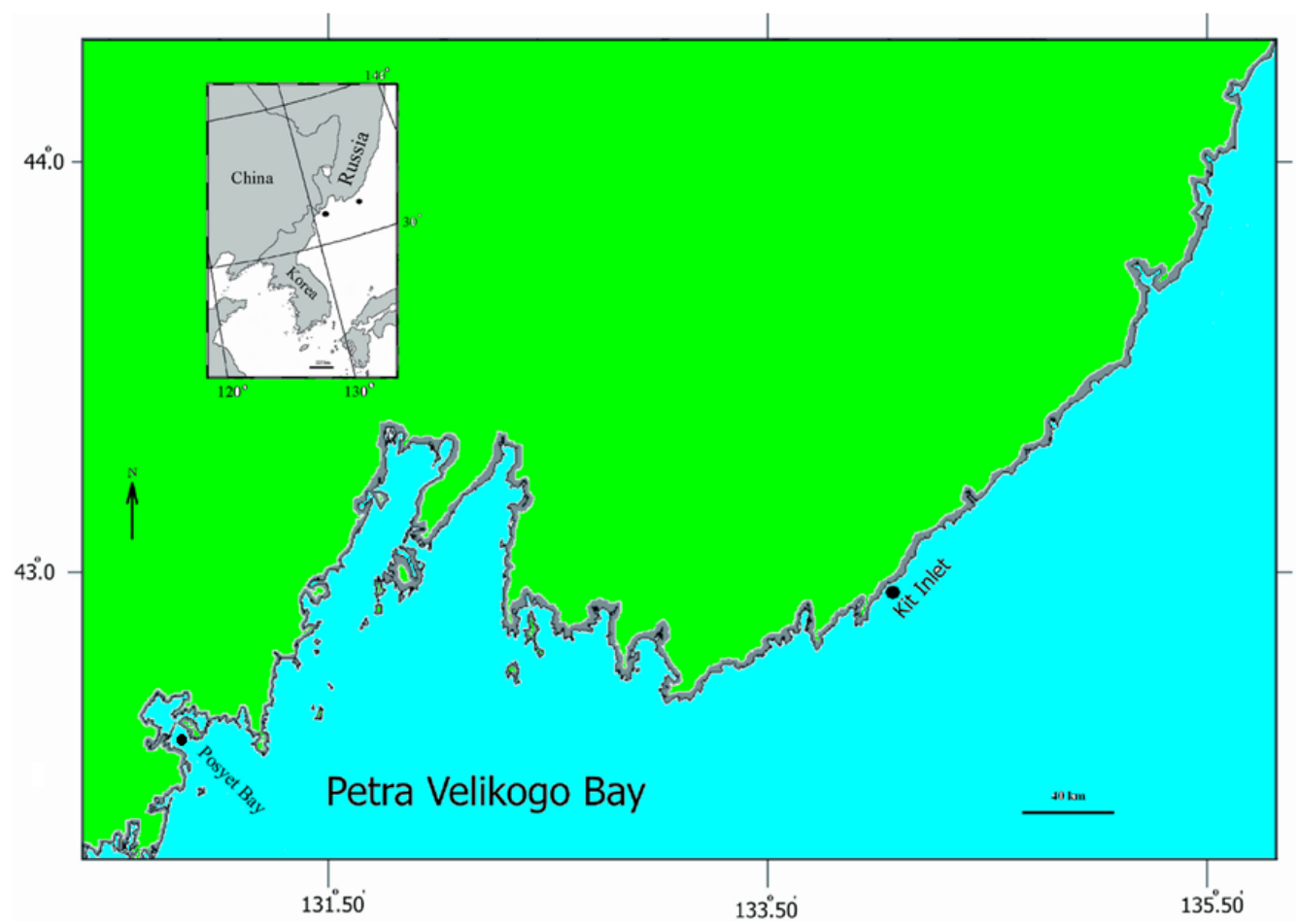

Fig. 1 Study area: St. 1-Minonosok Cove, St. 2-Kit Cove.

method of Ito, S. and co-authors [15]. The timing of the onset of spawning in bivalves was determined as an abrupt decrease, by $9-12 \%$, in the gonadal index. A week after spawning, plankton samples were collected with an Apstein net every two to three days from the horizon 0-10 $\mathrm{m}$ at one or three stations in Minonosok Cove and during four years at five stations in Kit Cove in 1977-1999. The mesh size of the mill screen was $100 \mu \mathrm{m}$. Plankton samples were fixed with $4 \%$ formaldehyde. Larvae were counted and measured in Bogorov's chamber under a MBS-10 microscope; number of larvae was expressed per $1 \mathrm{~m}^{3}$. After the scallop larvae reached $250 \mu \mathrm{m}$, three strings of collector-cages [16] with the mesh diameter of $5 \mathrm{~mm}$ were installed on the bottom of Minonosok Cove for three years. In addition, a few collector-cages were suspended at the cultivation facilities located in Minonosok Cove. In the algal plantations located north of Kit Cove, the collector-cages with a usual netting cover (mesh size $5 \mathrm{~mm}$ ) and a cover with a mesh size of $15 \mathrm{~mm}$ were suspended. In 1993, a collector-cage with the same netting cover was hung at a scallop farm in Minonosok Cove. After four months and in the spring of each year, as well as in the autumn of the second year, the collectors and the collector-cages were hauled up to the surface, cleaned of fouling organisms, and live and dead individuals of invertebrates were counted. At least 100 individuals of each species in each collector were measured with a vernier caliper to an accuracy of $\pm 0.1 \mathrm{~mm}$. A major amount of the work on scallop cultivation was conducted in 1977-1996 in Possyet Bay and in 1985-1988 in Kit Cove. The obtained data were analyzed statistically using the program STATISTICA 6.0 [17] and tested at the level of $\alpha=0.05$. At the measured animals counted up of average arithmetic and an error.

\section{Results and Discussion}

A collector-cage designed in 1981 for collecting and on-growing the scallop Patinopecten yessoensis has the interior partitioned into cones with platforms that protect bivalves from falling down and creating a high density there (Fig. 2). This reduces competition 
among bivalves and increases their survival and growth rates in comparison with those observed in constructions of the Japanese design [18]. In spite of the small mesh size of the netting cover of the collector-cages $(5 \mathrm{~mm})$ set up at the bottom, most $P$. yessoensis in them reached commercial size within three years; the growth rate of the commercial species Chlamys nipponensis (Fig. 3) was slightly lower. In the case the mesh size of the cover is increased to 15 $\mathrm{mm}, P$. yessoensis in the warm-water Minonosok Cove reaches $84.1 \pm 1.7 \mathrm{~mm}$ for three years; in the cold-water Kit Cove, $82.3 \pm 1.8 \mathrm{~mm}$. However, the survival rate of the warm-loving species $C$. nipponensis in warm-water Minonosok Cove was generally higher than that of the cold-loving $P$. yessoensis. It is worth noting that the slow-growing species found settled on the collector-cages (both $r$ and $\mathrm{K}$-strategists) showed a higher survival rate than the commercial species (Fig. 4). For three years of being under water, Japanese sea cucumber (Apostichopus japonicus), ascidians and sponges reach a marketable size in them. Within the first year, sea cucumber comes out of the collectors and either continues on it or detaches and moves to the bottom. Red king crab (Paralitodes camtschaticus) can also leave the collectors during molting. For three years of living on them, it reaches $31.8 \pm 5.1 \mathrm{~mm}$ in carapace width, while sea urchins (Strongylocentrotus nudus

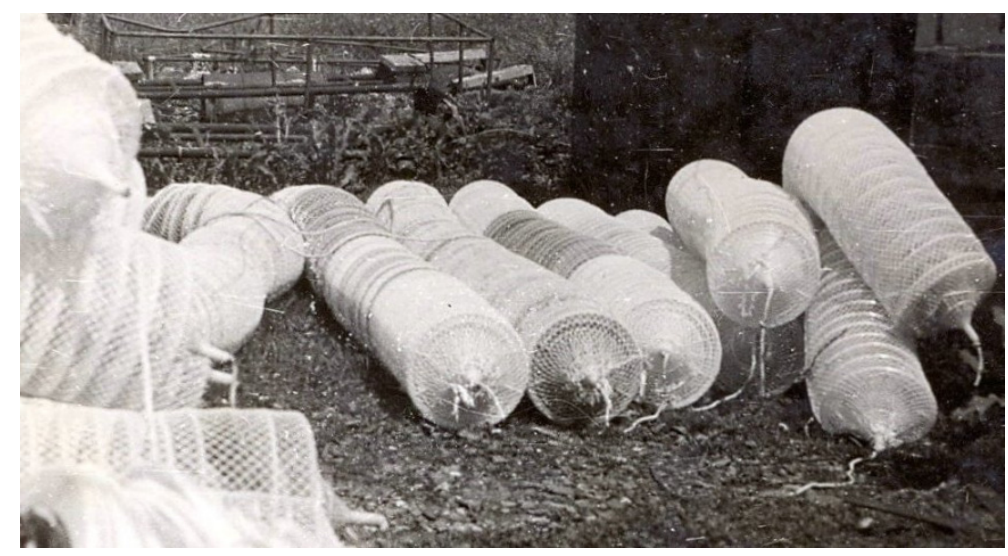

Fig. 2 Collector-cages before immersing in the sea.

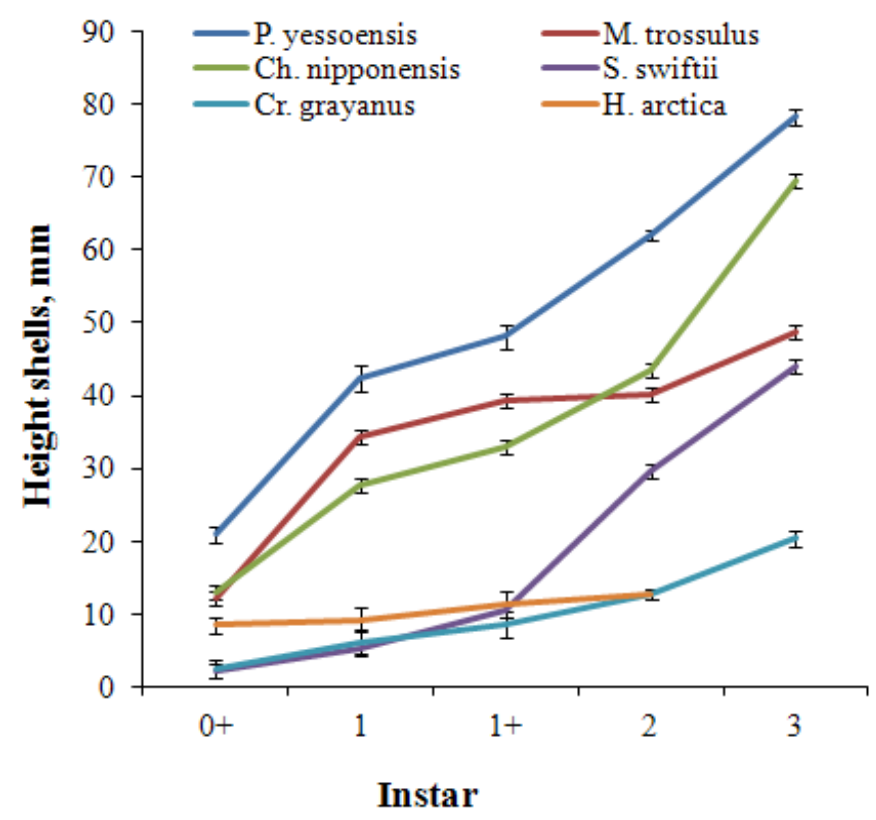

Fig. 3 Rates of growth of bivalve molluscs in collector-cages. 


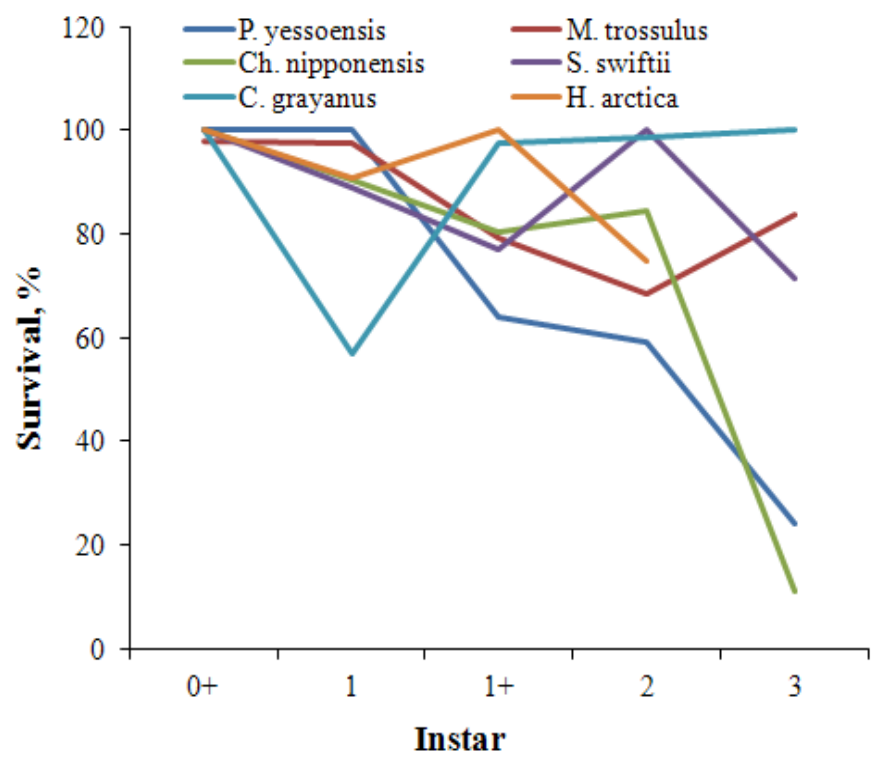

Fig. 4 Survival rate of bivalve molluses on collector-cages.

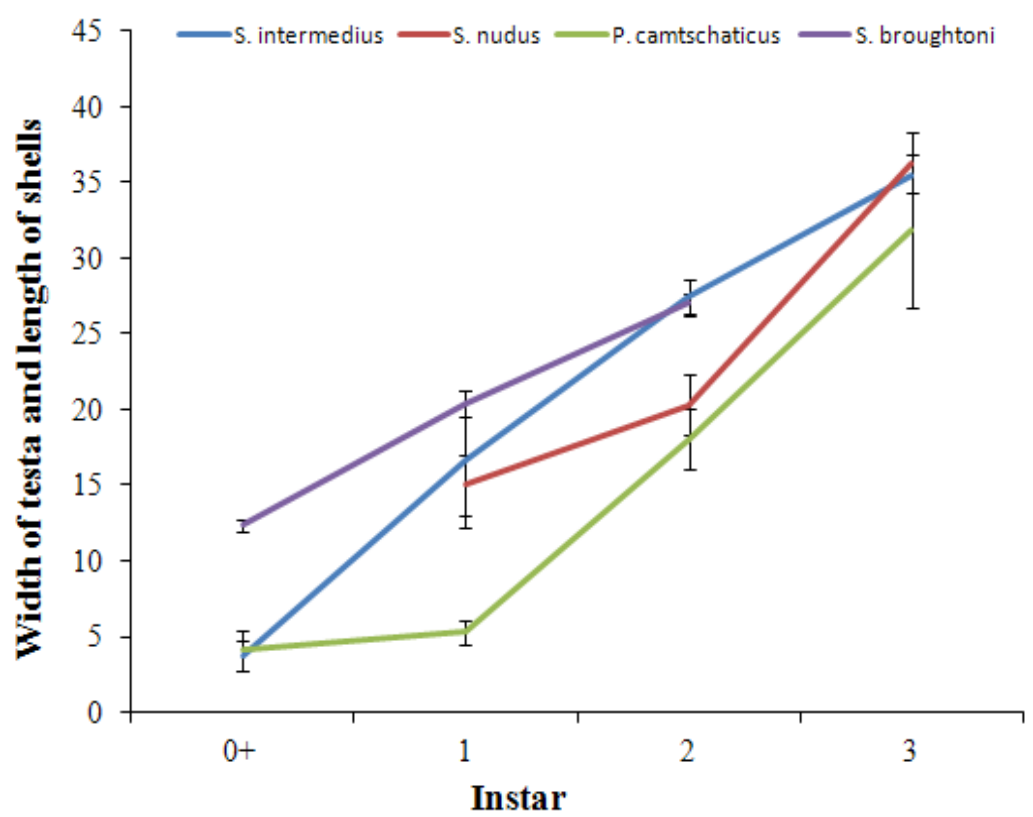

Fig. 5 Rates of growth of invertebrate in collector-cages.

and $S$. intermedius) become of a viable size (Fig. 5). The abundance of $A$. japonicus on collectors reaches 50 ind. $/ \mathrm{m}^{2} ;$ P. camschaticus, 4 ind. $/ \mathrm{m}^{2} ;$ S. intermedius, 25 ind. $/ \mathrm{m}^{2}$; Cucumaria japonica, 3 ind. $/ \mathrm{m}^{2}$; Styela clava, 60 ind. $/ \mathrm{m}^{2}$; Scapharca broughtoni, 2 ind. $/ \mathrm{m}^{2}$.

Predators and species accompanying the scallop exert a substantial impact on the cultivated object and on marine cultures [19-21]. However, our technology is supported by the fact that the animals and plants within the collector-cages create a multicultural community: mollusks, seaweed, shrimp and sea urchins produce DOM (Dissolved Organic Matter) used as food by bacteria [22] and phytoplankton [23, 24], on which bivalves actively feed [25, 26]. Cultivated mollusks are often resistant to fouling [27] and use mechanisms to protect themselves against predators [28], with some fouling organisms assisting them in this [29]. 
Some predators can have an adverse effect both on competitors of the scallop [30-32] and on other predators [33]. In addition, larvae of main scallop competitors such as the bay mussel Mytilus trossulus and the Japanese scallop Chlamys nipponensis, as well as the predatory seastar Asterias amurensis, settle in an upper horizon [34]; the productive years for M. trossulus and Ch. nipponensis mostly do not coincide with those for P. yessoensis [35]. Competitors tend to settle at other times, which can also be used to optimize the contents of collectors [10]. Touching the bottom with only the load (anchor), as well as the use of netting cover of the collector, prevents colonization of bivalve shells by drilling Polydora polychaete worms and barnacles, which retard the growth rate of bivalves at the bottom [36, 37]. The anchored position of collectors, in contrast to a hanged culture, reduces stress in cultivated species and increases the growth and survival rates in bivalves [38]. By the second and third years, much fewer invertebrate larvae settle on collector-cages [39]; the main competitor of the scallop, M. trossulus, does not live for more than two years in Possyet Bay [40]; and the overlapping cones in the inner part of collector prevents predators from moving in it.

\section{Conclusion}

These materials allow authors to draw a conclusion that aquaculture of bivalve mollusks provides the opportunity of obtaining a product without a damage to valuable accompanying species, and that the grown out bivalves will have a higher taste quality and useful properties, as they are cultivated in a natural environment.

\section{Acknowledgement}

Author is thankful to Shvetsov, E. P. for improving English language. The anonymous reviewers of this manuscript also receive the expression of authors' gratitude.

\section{References}

[1] Belogrudov, E. A. 1987. "Biology and Cultivation of
Japanese Scallops." In Cultivation of Pacific Invertebrate and Seaweed, edited by Morkovtsev, V. G, and Bregman, Y. E. Moskow: Agropromizdat.

[2] Gabaev, D. D. 1989. "Biological Substantiation of New Methods Cultivation of Some Trade Bivalve Molluscs in Primorye." Ph.D. thesis, The Far East Institute of Marine Biology.

[3] Dwernychuk, L. W., and Boag, D. A. 1972. "Ducks Nesting in Association with Gulls-An Ecological Trap?" Canadian Journal of Zoology 50 (5): 559-63.

[4] Zhuk, A. P., and Novoselova, E. C. 2009. "Organizational-economic Bases of Formations of a Control System by Innovative Activity in Mariculture Farms and Their Design Realisation (on an Example Primorsky Krai)." Proceedings of the Pacific Scientific Institute of Fish Economy and Oceanography 157: 312-27.

[5] Rakov, V. A. 1984. "Cultivation of Mollusks at France." Biology of Morya 1: 67-72.

[6] Hasegava, I. 1987. "Cultivation of Scallop." Taiye Gege 13.

[7] Claereboudt, M. R., Bureau, D., Côte, J., and Himmelman, J. H. 1994. "Fouling Development and Its Effect on the Growth of Juvenile Giant Scallops (Placopecten magellanicus) in Suspended Culture." Aquaculture 121: 327-42.

[8] Miron, G., Pelletier, P., and Bourget, E. 1995. "Optimizing the Design of Giant Scallop (Placopecten magellanicus) Spat Collectors: Flume Experiments." Marine Biology 123: 285-91.

[9] Pouliot, F., Bourget, E., and Fréchette, M. 1995. "Optimizing the Design of Giant Scallop (Placopecten magellanicus) Spat Collectors: Field Experiments." Marine Biology 123: 277-84.

[10] Chauvaud, L., Thouzeau, G., and Grall, J. 1996. "Experimental Collection of Great Scallop Postlarvae and other Benthic Species in the Bay of Brest: Settlement Patterns in Relation to Spatio-temporal Variability of Environmental Factors." Aquaculture International 4: 263-88.

[11] Soria, G., Lavín, M. F., Martínez-Tovar, I., and Macías-Duarte, A. 2013. "Recruitment of Catarina Scallop (Argopecten ventricosus) Larvae on Artificial Collectors off the NE Coast of the Gulf of California." Aquaculture Research 44: 1383-98. doi:10.1111/j.1365-2109.2012.03143.x.

[12] Fanelli, G., Prato, E., Parlapiano, I., and Biandolino, F. 2015. "Effect of Immersion Time on Scallops Settlement on Artificial Collectors (Taranto Gulf, Mediterranean Sea)." In Proceedings of the Aquaculture Europe, 1-3. Accessed March 16, 2015. https://www.was. org/easOnline/AbstractDetail.aspx $\mathbf{i}=3497$. 
[13] Prato, E., Biandolino, F., Parlapiano, I., Gianguzza, P., and Fanelli, G. 2015. "The Recruitment of Scallops (and beyond) by Two Different Artificial Collectors (Gulf of Taranto, Mediterranean Sea)." Aquaculture Research 47 (10): 3319-31. doi:10.1111/are.12785.

[14] Fréchette, M., Gaudet, M., and Vigneau, S. 2000. "Estimating Optimal Population Density for Intermediate Culture of Scallops in Spat Collector Bags." Aquaculture 183: 105-24.

[15] Ito, S., Kanno, H., and Takahashi, K. 1975. "Some Problems on Culture of the Scallop in Mutsu Bay." Bulletin Marine Biology Station Asamushi 15 (2): 89-100.

[16] Gabaev, D. D., and Lyvov, S. M. 1981. Collector for Artificial Cultivation of Mollusks. Rus. patent 826998, filed June 18, 1979, and issued May 7, 1981.

[17] Borovikov, V. P. 2003. STATISTICA: The Art of Computer Data Analysis for Professionals. St. Petersburg: Piter.

[18] Gabaev, D. D. 2017. "About Through-Cultivation of Two Commercial Bivalve Molluscs." Journal of Aquaculture \& Marine Biology 5 (5): 00131.

[19] Lodeiros, C. J. M., and Himmelman, J. H. 1996. "Influence of Fouling on the Growth and Survival of the Tropical Scallop, Euvola (Pecten) ziczac (L. 1758) in Suspended Culture." Aquaculture Research 27: 749-56.

[20] Su, Z., Xiao, H., Yan, Y., and Huang, L. 2008. "Effect of Fouling Organisms on Food Uptake and Nutrient Release of Scallop (Chlamys nobilis, Reeve) Cultured in Daya Bay." J. Ocean Univ. Chin. (Oceanic and Coastal Sea Research) 7 (1): 93-96. doi:10.1007/s11802-008-0093-2.

[21] Aquilar, R. E. L. 2011. "Problem of Biofouling in the Culture of Argopecten purpuratus in Peru." Revista AquaTIC 35: 9-19. Accessed December 20, 2011. http://www.revistaaquatic.com/aquatic/art.asp?t=p\&c=24 3.

[22] Weiss, M., and Simon, M. 1999. "Consumption of Labile Dissolved Organic Matter by Limnetic Barterioplankton: The Relative Significance of Amino Acids and Carbohydrates." Aquat. Microb. Ecol. 17 (1): 1-12.

[23] Solovyeva, A. L., Galkina, V. N., and Garkovskaya, G. P. 1977. "Experimental Studying of Influence of the Dissolved Organic Substance of Metabolite of Mussels on Natural Community of a Phytoplankton of the White Sea." Oceanology 17 (3): 449-58.

[24] LeBlanc, A. R., Landry, T., and Miron, G. 2003. "Fouling Organisms of the Blue Mussel Mytilus edulis Their Effect on Nutrient Uptake and Release." Journal of Shellfish Research 22 (3) 633-8.

[25] Mikulich, L. V., and Tsychon-Lukanina, E. A. 1981. "Structure of Food of the Japanese Scallop." Oceanology 21 (5): 894-7.

[26] Amouroux, J. M. 1984. "Preliminary Study on the
Consumption of Dissolved Organic Matter (Exudates) of Bacteria and Phytoplankton by the Marine Bivalve Venus verrucosa." Marine Biology 82 (2): 109-12.

[27] Carraro, J. L., Rupp, G. S., Mothes, B., Lerner, C., and Würdig, N. L. 2012. "Characterization of the Fouling Community of Macroinvertebrates on the Scallop Nodipecten nodosus (Mollusca, Pectinidae) Farmed in Santa Catarina, Brazil." Ciencias Marinas 38 (3): 577-88. doi:10.7773/cm.v38i3.1982.

[28] Freeman, A. S., Meszaros, J., and Byers, J. E. 2009. "Poor Phenotypic Integration of Blue Mussel Inducible Defenses in Environments with Multiple Predators." Oikos 118: 758-66. doi:10.1111/j.1600-0706.2008.17176.x.

[29] Farren, H. M., and Donovan, D. A. 2007. "Effects of Sponge and Barnacle Encrustation on Survival of the Scallop Chlamys hastata." Hydrobiologia 592 (1): 225-34. Accessed July 05, 2007. https://doi.org/10.1007/s10750-007-0743-1.

[30] Gabaev, D. D., and Kolotukhina, N. K. 1999. "The Effect of Predation by Nucella (Thais) heyseana on Population of Japanese Scallop Mizuhopecten yessoensis (Jay)." Russian Journal of Ecology 30 (2): 133-5.

[31] Ross, K. A., Thorpe, J. P., and Brand, A. R. 2004. "Biological Control of Fouling in Suspended Scallop Cultivation." Aquaculture 229: 99-116. doi:10.1016/S0044-8486(03)00328-4.

[32] Cook, E. J., and Kelly, M. S. 2009. "Co-culture of the Sea Urchin Paracentrotus lividus and the Edible Mussel Mytilus edulis L. on the West Coast of Scotland United Kingdom." Journal of Shellfish Research 28 (3): 553-9. Accessed January 8, 2009. https://doi.org/10.2983/035.028.0318.

[33] Dernbach, E. M., and Freeman, A. S. 2015. "Foraging Preference of Whelks Nucella lapillus in Robust to Influences of Wave Exposure and Predator Cues." Mar. Ecol. Prog. Ser 540: 135-44. Accessed November 26, 2015. https://doi.org/10.3354/meps 11491.

[34] Gabaev, D. D. 1982. "Settlement of Larvae of Bivalve Mollusks and Starfishes on Collectors in Posyet Bay (Sea of Japan)." Biology of Morya 7 (4): 263-8.

[35] Gabaev, D. D. 2009. "Dynamics of the Abundance of Some Bivalve Species in Russian Waters of the Sea of Japan and Its prognosis.” Oceanology 49 (2): 218-27.

[36] Ovsyannikova, I. I., and Levin, V. S. 1982. "Growth Dynamics of Barnacle Solidobalanus hesperius on the Shucks of Japanese Scallop at the Bottom Cultivation." Biology of Morya 4: 44-51.

[37] Gabaev, D. D. 2013. "Effects of Fouling on the Japanese Scallop Mizuhopecten yessoensis (Jay) in Peter the Great Bay (Sea of Japan)." Oceanology 53 (3): 183-91.

[38] Hunauld, P., Vélez, A., Jordan, N., Himmelman, J. H., 
Morales, F., Freites, L., et al. 2005. "Contribution of Food Availability to the More Rapid Growth of the Scallop, Euvola ziczac (Pteroida, Pectinidae) in Bottom than in Suspended Culture." Revista De Biologia Tropical 53 (3-4): 455-61. Accessed August 10, 2005. https://doi.org/10.15517/rbt.v53i3-4.14614.

[39] Gabaev, D. D. 2008. "Through-cultivation of Trade
Bivalve Molluscs." Fishery Questions 9 (1): 218-43. Accessed March 8, 2008. http://hdl.handle.net/123456789/2998.

[40] Gabaev, D. D. 2007. "Succession and Climax at Fouling of Artificial Substrates in Posyet Bay, Sea of Japan." In Proceeding of the Seventh (VII) Conference on Studying of Molluscs St. Petersburg: Piter, 69-71. 